\title{
DIAGNOSIS OF SENSOR FAULTS IN A COMBUSTION ENGINE CONTROL SYSTEM WITH THE ARTIFICIAL NEURAL NETWORK
}

\section{Iwona KOMORSKA ${ }^{1}$, Zbigniew WOLCZYŃSKI $^{2}$, Artur BORCZUCH $^{3}$}

University of Technology and Humanities in Radom, Faculty of Mechanical Engineering, Department of Automotive Mechatronics

${ }^{1}$ iwona.komorska@uthrad.pl, ${ }^{2}$ z.wolczynski@uthrad.pl, ${ }^{3}$ a.borczuch@uthrad.pl

\section{Abstract}

The work presents the investigations carried out on a spark-ignition internal combustion engine with gasoline direct injection. The tests were carried out under conditions of simulated damage to the air temperature sensor, engine coolant temperature sensor, fuel pressure sensor, air pressure sensor, intake manifold leakage, and air flow disturbances. The on-board diagnostic system did not detect any damage because the sensor indications were within acceptable limits. The engine control system in each case changed its settings according to the adaptive algorithm. Signal values in cycles from all available sensors in the engine control system and data available in the on-board diagnostic system of the car were recorded. A large amount of measurement data was obtained. They were used to create a statistical function that classifies sensor faults using an artificial neural network. A set of training data has been prepared accordingly. During learning the neural network, a hit rate of over $99 \%$ was achieved.

Keywords: combustion engine, sensor fault diagnosis, artificial neural network

\section{DIAGNOZOWANIE USZKODZEŃ CZUJNIKÓW W SYSTEMIE STEROWANIA SILNIKA SPALINOWEGO Z WYKORZYSTANIEM SZTUCZNEJ SIECI NEURONOWEJ}

\section{Streszczenie}

W pracy przedstawiono badania przeprowadzone na silniku spalinowym o zapłonie iskrowym $\mathrm{z}$ bezpośrednim wtryskiem paliwa. Testy wykonano w warunkach symulowanych uszkodzeń czujników temperatury powietrza, temperatury cieczy chłodzącej silnik, ciśnienia paliwa, ciśnienia powietrza, nieszczelności w kolektorze dolotowym, zaburzenia przepływu powietrza. System diagnostyki pokładowej nie wykrył żadnego uszkodzenia, ponieważ wskazania czujników mieściły się w granicach tolerancji. System sterowania silnika w każdym przypadku zmieniał swoje ustawienia według adaptacyjnego algorytmu. Rejestrowano cyklowe wartości sygnałów ze wszystkich dostępnych czujników w systemie sterowania silnika oraz dane dostępne w systemie diagnostyki pokładowej samochodu. Otrzymano dużą ilość danych pomiarowych. Wykorzystano je do utworzenia statystycznej funkcji klasyfikującej uszkodzenia przy pomocy sztucznej sieci neuronowej. Odpowiednio przygotowano zbiór danych uczących. W trakcie uczenia sieci neuronowej osiągnięto współczynnik trafień powyżej $99 \%$.

Słowa kluczowe: silnik spalinowy, diagnozowanie uszkodzeń czujników, sztuczna sieć neuronowa

\section{INTRODUCTION}

The control system of the gasoline engine requires information about its current condition. Several types of sensors are used in the gasoline engine control system. An extensive description of their construction and operation can be found in [13]. Wrong indications or lack of strategic sensors (e.g. of crankshaft position) preclude the work of the engine. Signals from the remaining sensors (e.g. air flowmeter) burdened with an error cause an inappropriate working of the control system and non-optimal work of the engine.

The role of the on-board diagnostics is a supervision over all elements of the control system including sensors. The system reacts to damages causing an increase in the emission of toxic exhaust components or a significant increase in fuel consumption [4]. Therefore, some of the defects, such as a change in sensor characteristics, remain unnoticed. In such cases, the adaptive control system adapts other control parameters (e.g. start of injection, spark advance, duration of fuel injection) so as to compensate for the changes [5-8].

Damages of the sensors can take place because of many reasons. There are mechanic damages easy to visual identification. Electric damages of the sensors undetectable visually are very frequent. Such damages can result in the signal giving wrong information or the lack of the signal. If as a result of the wrong working of the sensor its output signal goes beyond the bounds accepted for the particular 
sensor, the system of the on-board diagnostics interprets it as an error of the sensor. If wrong working of the sensor is based on the shifting its characteristics but the output signal does not go beyond the bounds accepted for it, such damage remains unnoticed.

The self-diagnosis system is an algorithm realized in the controller which is supposed to detect faults. It analyses signals coming from the sensors. It may be possible that the wrong value of the signal is not the result of damaging the sensor but the wire linking the sensor with the controller. Damage to the wires can be based on shorting, interruption and appearing a certain resistance between the wires or between the wire and car body. The system of on-board diagnostics can detect the first two damages from those ones mentioned above and will indicate the fault. In the case of appearing a certain (finished) resistance between the wires, the signal from the sensor can be moved by a constant value (Fig.1). In such a situation, the damage will not be detected and the engine will be controlled on the basis of false information.

The controller will work in the same way when as a result of a faulted sensor its signal is changed by a certain value. The shifting of the signal by a constant value usually occurs in the entire extent of the output signal. The damages of the sensors can also be based on the change of its characteristics. Most frequently in the case of linear characteristics, this is a change of its slope and/or shifting by a constant value (Fig. 1a).

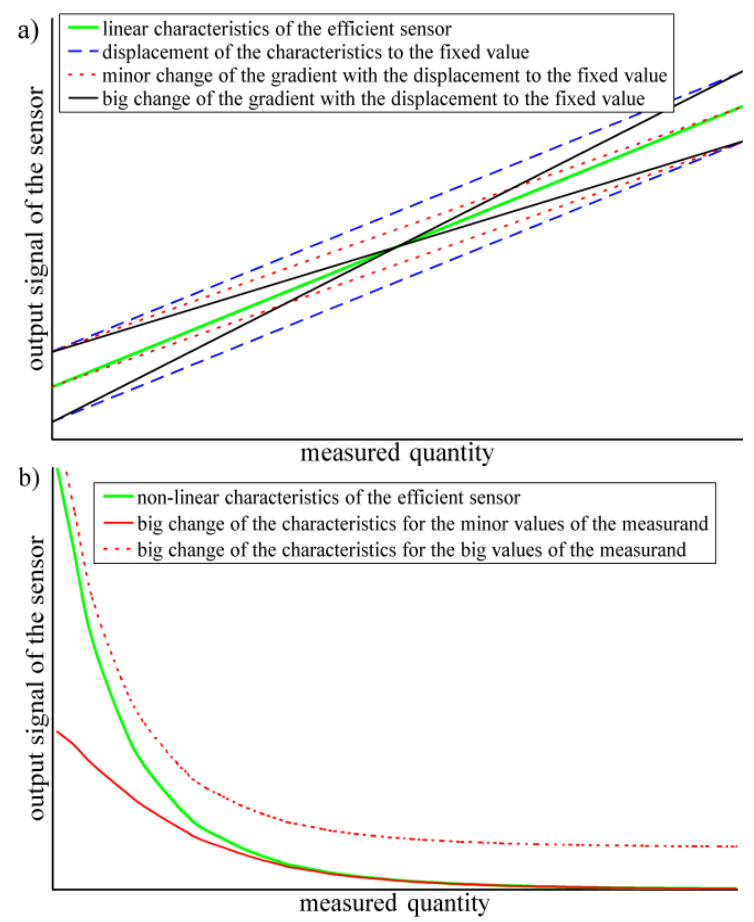

Fig. 1. Characteristics of sensors a) linear, b) non-linear and its exemplary changes for damaged sensor
Linear characteristics are provided by potentiometric sensors: accelerator pedal position, throttle position, atmospheric pressure, fuel pressure, air pressure in the intake channel, as well as volumetric air flow meter used in the tested vehicle.

In the case of sensors of non-linear characteristics, shifting by a constant value of the output signal strongly disturbs the survey only for low or high measured values (Fig. 1b). Non-linear characteristics are provided by hot-film air flowmeters, air and coolant temperature sensors.

Aging sensors work in a similar way. Their characteristics submit little changes with time. This is a process that concerns most of the sensors during the maintenance of the car. Controllers are equipped with the adaptive control system to minimize errors of controlling the engine as a consequence of the aging sensors. The adaptive system ,learns" during the maintenance of the car and corrects controlling of the engine taking account of the indication changes of the aging sensors.

In such a case, controlling the engine will be corrected on the basis of changed characteristics of the sensor that will not give optimal results of its working. Deterioration of the engine performance can be based on the increase of the emission of toxic compounds, the loss of power and torque or the increase of fuel consumption.

Fig. 2 shows the graph of engine torque and power versus the rotational speed for an efficient engine and fault-free sensor indications. Next, the error of the air flowmeter indication in the manifold was simulated by the flow disorder. During the subsequent test, the adaptive control system adjusts its settings, but for many speed values, it achieves lower power and torque values, especially in the high-speed range.

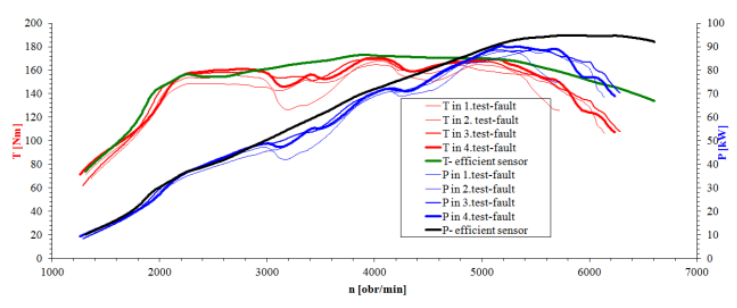

Fig. 2. Torque and Power vs. rpm of engine for a fault-free state and simulated fault of flowmeter

The on-board diagnostic system is oriented towards the detection of faults which cause an increase of the exhaust gas emission. In the case of mechanical faults in the air intake system or changes of the sensor characteristics, the control system tries to mask faults adjusting - as far as possible - the engine control [9].

The modern on-board diagnostics system often uses virtual sensors in the combustion engine. Based on the indications of other sensors 
recognized as efficient and relations of mathematical or statistical models, the rational indications investigated sensors are estimated and compared with the indication of the physical sensors [10-15].

Because of the product variety and structural complexity of automobiles, the traditional diagnosis technologies were difficult to meet the requirements of fault detection and maintenance. In order to improve the diagnosis and maintenance level of faults, the application of neural network method of sensor fault diagnosis was studied.

\section{DESCRIPTION OF EXPERIMENTS}

The investigation was conducted on the fourcylinder spark ignition engine of a gasoline direct injection (GDI) of passenger car Mitsubishi Carisma (Fig. 3). The car was positioned on a chassis dynamometer. It was possible to brake a vehicle or the engine with the given moment, or accelerated to the given speed. In such a way the vehicle engine was loaded to the required and simultaneously constant speed $n$ at various throttle position TPS.

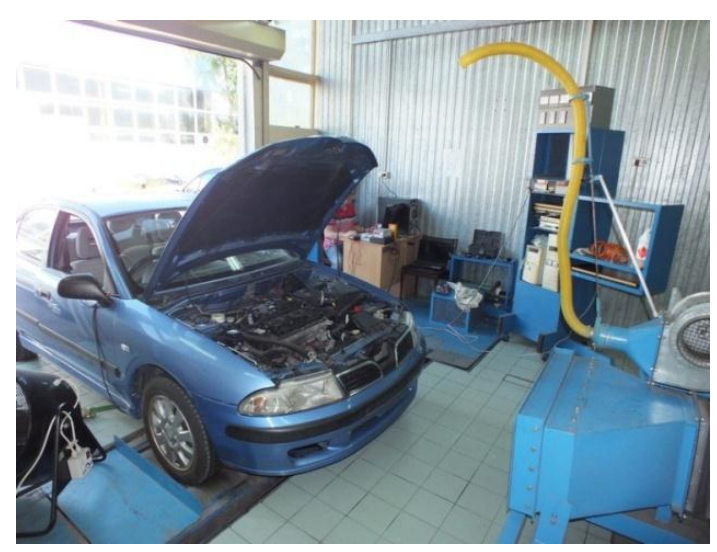

Fig. 3. Experimental setup

Some investigations were planned in order to verify the method of sensors fault detection in the control system of the SI engine with the gasoline direct injection (GDI). It differs from the fuelling system of the SI engine with the indirect injection of fuel. The basic difference is the work of the engine with very poor mixtures. It takes place at low and medium rotational speeds and loads. Then, the laminar mixture is burned in the engine. The average composition of such a mixture determined by air-fuel ratio $\lambda$ varies from 1.8 to 2.5 . Surveys were conducted in a situation when the engine was working with the homogenous mixture.

The sensors submitted to examination include volumetric air flowmeter, the air pressure sensor, the air temperature sensor, the manifold pressure sensor, the engine temperature sensor, and the fuel pressure sensor. The survey of the work parameters of the engine with the entire functional control system was carried out. Next, faults of particular sensors were simulated and the survey was conducted one more time.

Taking into consideration the fact that the indication errors can be displayed at different rotational speeds of the engine as well as at different loads, the studies were carried out at three loads and seven rotational speeds. The loads were given by setting the voltage at the output of the accelerator pedal position sensor. Some voltages were in a line with no-load running, $17 \%, 34 \%$ and $100 \%$ of the extent of its variability. The rotational speed was set by applying the brake load to the engine. The surveys were conducted with the speeds of no-load running, 1000, 1500, 2500, 3000, 3500 and $4000 \mathrm{rpm}$.

The following indication errors of the sensor were simulated:

- shifting the characteristics of the air temperature sensor by adding additional resistance so that instead of the temperature of $31^{\circ} \mathrm{C}$ it indicated $44^{\circ} \mathrm{C}$,

- shifting the characteristics of the air temperature sensor by adding additional resistance so that instead of the temperature of $33^{\circ} \mathrm{C}$ instead of $19^{\circ} \mathrm{C}$,

- shifting the characteristics of the liquid coolant temperature sensor by adding additional

- resistance in a way that it pointed $106^{\circ} \mathrm{C}$ instead of $86^{\circ} \mathrm{C}$,

- shifting the characteristics of the liquid coolant temperature sensor by adding additional

- resistance in a way that it pointed $58^{\circ} \mathrm{C}$ instead of $87^{\circ} \mathrm{C}$,

- shifting the characteristics of the air pressure sensor by shifting the output voltage in a way that it pointed $109 \mathrm{kPa}$ instead of $98 \mathrm{kPa}$,

- shifting the characteristics of the air pressure sensor by shifting the output voltage in a way that it pointed $87 \mathrm{kPa}$ instead of $98 \mathrm{kPa}$,

- change of the characteristics of the volumetric air flowmeter by partial obscuring the measuring channel,

- shifting the characteristics of the fuel pressure sensor by decreasing the output voltage in a way that it pointed pressure $2 \mathrm{MPa}$ higher than the actual one,

- shifting the characteristics of the fuel pressure sensor by increasing the output voltage in a way that it pointed pressure $2 \mathrm{MPa}$ lower than the actual one,

- changing manifold pressure by making little air leakage,

- changing manifold pressure by making bigger air leakage.

The on-board diagnostics (OBD) system has not detected any of the simulated faults during the studies.

The following one-second window of signals was registered for the efficient control system and all faults of the sensors mentioned above:

- from the crankshaft position sensor, 
- from the camshaft position sensor,

- controlling the fuel injector for the first cylinder,

- controlling the ignition coil of the first cylinder,

- from the volumetric flowmeter,

- from the manifold pressure (MAP) sensor,

- from the analyzer of mixture composition MEXA-700ג,

- from the fuel pressure sensor.

Next, the following parameters in the control system of the engine for each working cycle were determined:

- value of rotational speed $n$,

- value of the spark advance angle $k_{\mathrm{wz}}$,

- value of volumetric air flow rate filling the engine $V_{\mathrm{A}}$,

- values of the injector opening angle $k_{\mathrm{w}}$

- duration of the fuel injection $t_{\mathrm{w}}$,

- value of the manifold absolute pressure MAP,

- the air-fuel ratio determined by the factor $\lambda$,

- fuel pressure in the board powering the injectors $p_{\mathrm{F}}$.

\section{ANALYSIS OF TEST RESULTS}

The adaptive engine control system attempts to match the control parameters, such as the duration and start of fuel injection, the spark advance angle, so as to get as close as possible to the air-fuel ratio $\lambda$, given by the algorithm. Fig. 4. presents the results of $\lambda$ measured for various types of sensor damage.

a)

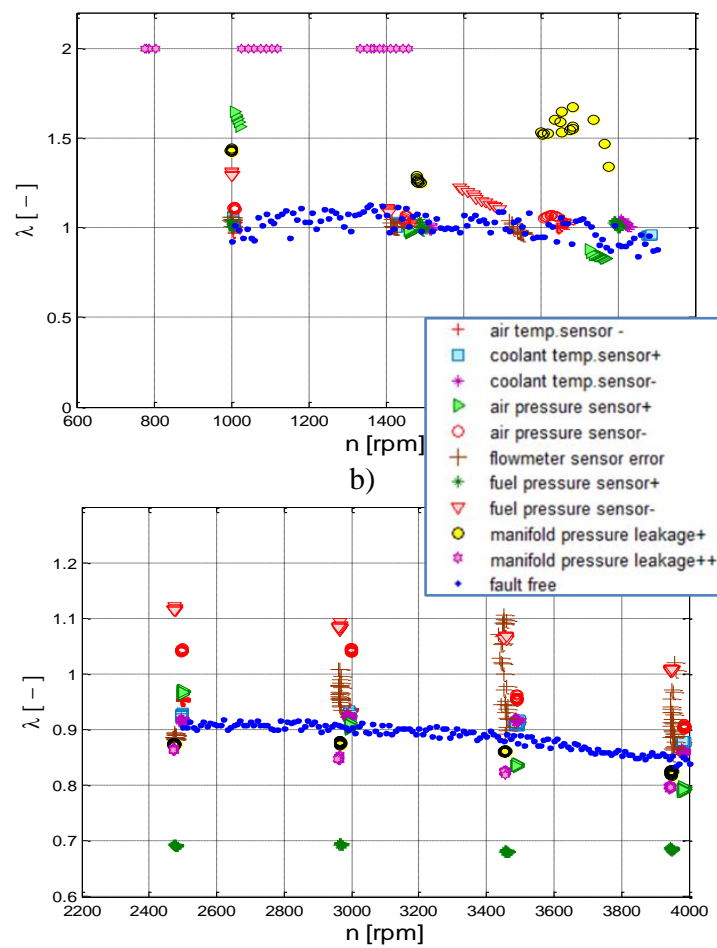

Fig. 4. Air fuel ratio vs. rpm for fault-free and different sensor faults

a) $17 \%$ throttle valve opening

b) $100 \%$ throttle valve opening
For small engine loads (Fig. 4a) in the case of most incorrect sensor indications, the control system selects the duration of fuel injection so that the set level $\lambda$ (blue points) is achieved. For leakage in the intake manifold, the air-fuel ratio increases up to 2 . The increase in $\lambda$ can also be seen for the faulty (+) indication of the air pressure sensor and the fuel pressure sensor (-). The biggest changes can be noted for a speed of $1000 \mathrm{rpm}$.

In the case of the highest engine loads (Fig. 4b), a similar level of coefficient $\lambda$ to the original one can be achieved only for faulty indications of the air temperature and coolant temperature sensor.

Fig. 5 and 6 summarize the control parameters matched by the adaptive control system in the cases of various sensor failures. Blue points are a pattern for a state without damage. Fig. 5 refers to low engine loads (17\% throttle opening), while Fig. 6 shows the control parameters for full throttle opening.

a)

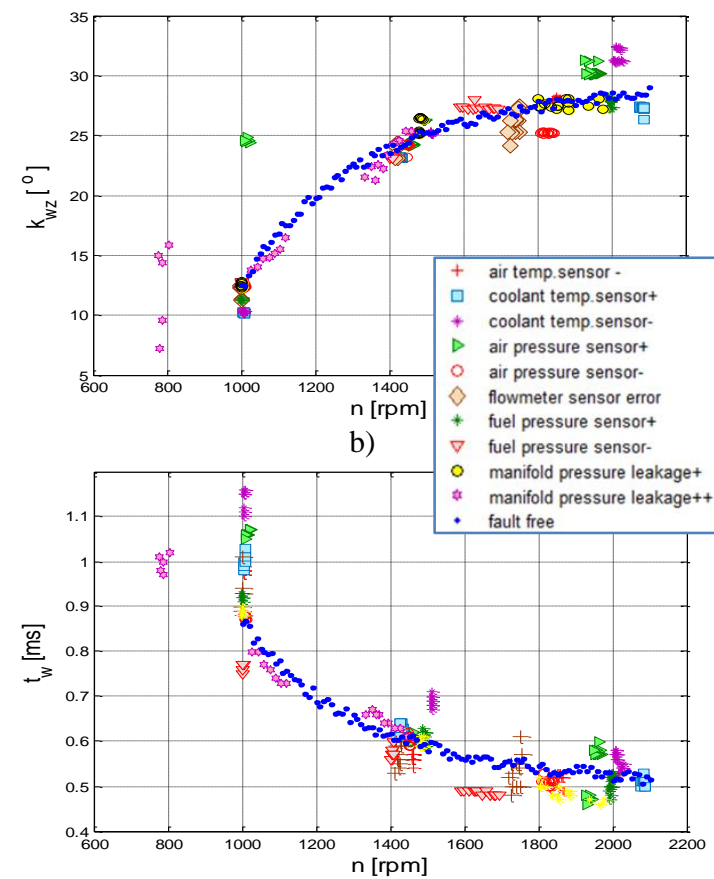

c)

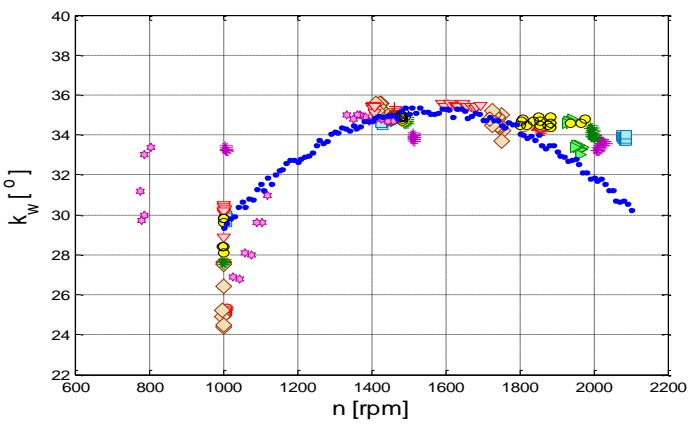

Fig. 5. Engine control parameters for $17 \%$ throttle valve opening and different sensor faults

a) spark advance vs. rpm

b) fuel injection duration vs. rpm

c) start of injection angle vs. rpm 
The set of sensor indications and control parameters are so unique for each sensor damage that an error can be deduced from them. The presented data are for one type of engine. In control systems of other manufacturers, other power, etc., the control system will adjust the parameters according to a different algorithm, so it is difficult to set rigid rules during the diagnosis.

a)

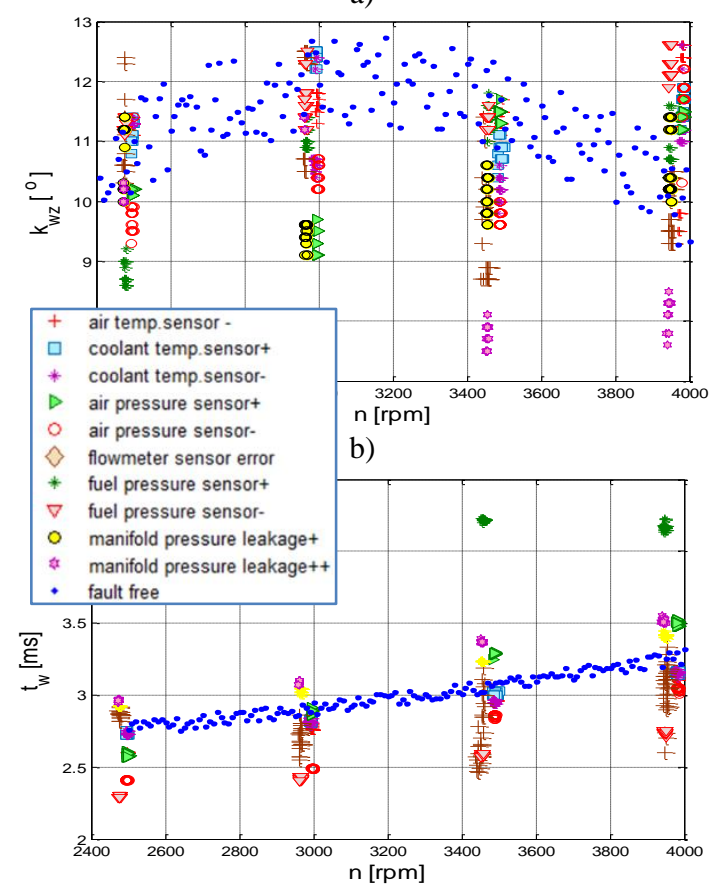

c)

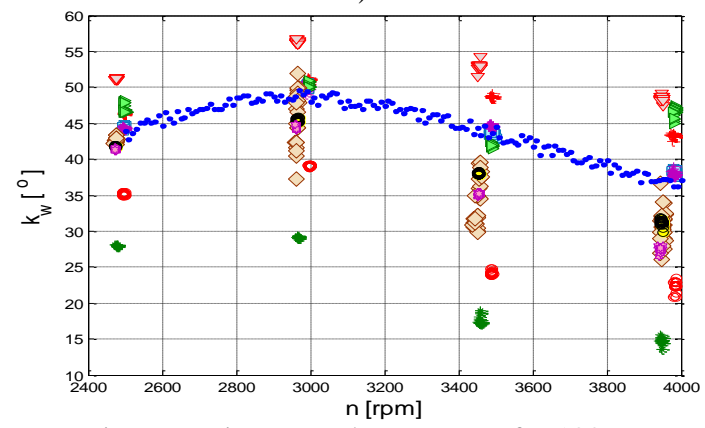

Fig. 6. Engine control parameters for $100 \%$ throttle valve opening and different sensor faults

a) spark advance vs. rpm

b) fuel injection duration vs. rpm

c) start of injection angle vs. rpm

Machine learning methods allow you to analyze a large amount of data. This work uses artificial neural networks in the task of identifying and classifying the sensor faults.

\section{FAULT CLASSIFICATION WITH ARTIFICIAL NEURAL NETWORKS}

Artificial Neural Networks (ANN) can work easily with non-linearly separable data, and this makes them ideal for applications such as fault detection and classification, where the training data are sparse, and the network will have to generalize well. Several applications have demonstrated that a neural network can successfully recognize and classify different faults in a number of different condition monitoring applications [16-22]. A good general introduction to neural networks is provided by $[23,24]$.

The Matlab ANN Toolbox was used for the modeling. Feedforward backpropagation is the network structure with a Levenberg-Marquardt backpropagation training function and a backpropagation weight and bias learning function. A two-layer feed-forward network was used as it can approximate any function with a finite number of discontinuities given sufficient neurons in the hidden layer.

Based on the analysis of the measurement results, it was determined that two areas of engine operation should be selected for the diagnosis:

a. low load and speed about $1000 \mathrm{rpm}$ and

b. full load and speed of about 4,000 rpm.

There are 9 parameters for the network input:

- engine rotational speed $n$,

- throttle position TPS,

- spark advance angle $k_{\mathrm{wz}}$,

- volumetric air flow rate filling the engine $V_{A}$,

- start of injection angle $k_{w}$,

- duration of the fuel injection $t_{w}$,

- manifold absolute pressure $M A P$,

- air-fuel ratio $\lambda$,

- fuel pressure $p_{F}$.

At the output, twelve classes of states were defined, corresponding to the tested sensor faults and described in chapter 3. Samples obtained at the experimental stage were randomly divided into three groups to train $(70 \%$ of the samples $=325$ samples), validate $(15 \%$ of the samples $=69$ samples) and test (15\% of the samples $=69$ samples)) the neural networks with a random data

division function. Training samples were introduced during the training and the network was adjusted according to the error. Validation samples were used to measure network generalization and stop the training when the generalization stopped improving. Testing samples have no effect on training and so provide an independent measure of a network's performance. The LevenbergMarquardt backpropagation algorithm automatically stops training when generalization ceases to improve, as an increase in the mean square error of the validation samples indicates.

The network contains an output layer with 12 neurons because there are 12 data classes and one hidden layer. Tests were conducted to determine the best number of neurons in the hidden layer. The values from 8 to 16 neurons were considered. Various activation functions were tested. Two criteria were assessed:

- percent error $(\% \mathrm{E})$ - the fraction of samples which are misclassified and

- minimizing cross-entropy (CE) results in good classification. 
The best results were obtained for 14 neurons in the hidden layer for the 'tansig' activation function (sigmoid tangent) described by

$$
a=\operatorname{tansig}(n)=\frac{2}{1+e^{-2 n}}-1
$$

where $n$ is the sum of the weighted outputs.

In the output layer, the 'softmax' activation function has been used, which is an exponential function with a normalized value in such a way that the sum of the activation for the entire layer is equal to 1 , described by

$$
a=\operatorname{softmax}(n)=\frac{e^{n}}{\sum_{i} e^{n_{i}}} .
$$

The structure of the network is shown in Fig. 7.

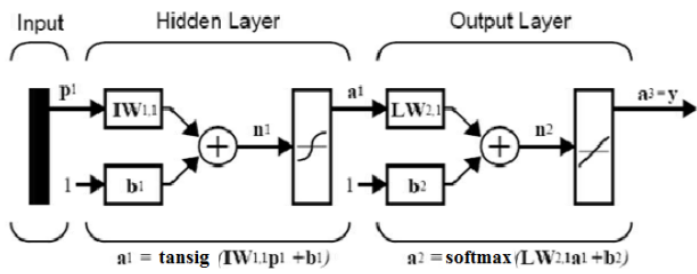

Fig. 7. Two-layer tansig/softmax network developed with Matlab

There was one error while training the network one data sample for 'air temperature sensor+' was qualified as 'flowmeter sensor error'. There was also one error during validation - one data sample for 'air pressure sensor+' was qualified as 'flowmeter sensor error'. Testing went without errors. The whole matrix of errors is presented in Fig.8. Numbers on the diagonal of the matrix indicate the number of correctly classified samples. The overall hit score was $99.6 \%$.

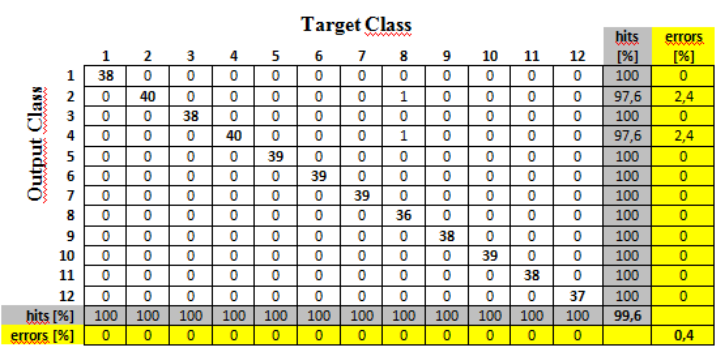

Fig. 8. Summary Confusion matrix for training, validation and test

\section{CONCLUSIONS}

The investigation confirmed that the control system of the automotive engine is highly robust in that individual sensor failures are occurred and the control system is dynamically reconfigured for uninterrupted operation. Eleven faulty sensor indications were examined. Since in no case the sensor's indication exceeded the set limits, the onboard diagnostic system did not notice an error. In each case, the adaptive control system adjusted its control parameters so that the engine would work as well as possible (ecologically).

In some cases, adaptation is not beneficial. The engine under test works on poor mixtures and it is sometimes difficult to detect the cause of its work that deviates from the norm (eg with reduced power). Therefore, a system for diagnosing sensor faults based on a neural network with one hidden layer has been developed. The tests were satisfactory because more than $99 \%$ of hits were obtained. The good obtained result relates to a single sensor failure during one test. When building applications, multiple failures in many tests should be tested.

The use of artificial intelligence methods allows for the automation of the diagnostic procedure. With a large amount of measurement data, fault classifications can be made without developing rules, especially since each control system has its own adaptive algorithm.

The article presents only one of the methods of machine learning. Other methods of machine learning methods as decision trees or support vector machine can be successfully used.

\section{REFERENCES}

1. Jurgen RK. Automotive Electronics Handbook. McGraw-Hill. New York 1995.

2. Turner J. Automotive sensors. Momentum Press. New York 2009.

3. Reif K. Gasoline engine management. systems and components. Springer-Vieweg 2015. https://doi.org/10.1007/978-3-65803964-6.

4. Merkisz J, Pielecha J, Radzimirski S. New trends in emission control in the European Union. Springer. 2014.

5. Karagiorgis S, Glover K, Collings N. Control challenges in automotive engine management. European Journal of Control 2007;13:92-104. https://doi.org/10.3166/EJC.13.92-104.

6. Tang H, Weng L, Dong ZY, Yan R. Adaptive and Learning Control for SI Engine Model With Uncertainties. Mechatronics. IEEE/ASME Trans. 2009.14(1):93-104. https://doi.org/10.1109/TMECH.2008.2004806.

7. Alt B, Svaricek F. Robust control design for automotive applications: A variable structure control approach. In book: Challenges and paradigms in applied robust control. Intech Open 2011. https://doi.org/10.5772/16724.

8. Djemili I, Aitouche A, Cocquempot V. Fault tolerant control of internal combustion engine subject to intake manifold leakage. IFAC Proc. 2012;45(20): 600-605. https://doi.org/10.3182/20120829-3-MX2028.00268 .

9. Dąbrowski Z, Madej H. Masking mechanical damages in the modern control systems of combustion engines. Journal of Kones Powertrain and Transport. 2006; 13(3): 53-60.

10. Dutka A, Javaherian H, Grimble M. Model-based engine fault detection and isolation. Proceedings of American Control Conference ACC '09 2009: 4593 4600 . 
11. Isermann R. Model-based fault detection and diagnosis - status and applications. Annual Reviews in Control. 2005; 29: 71-85.

12. Nyberg M, Nielsen L. Model Based Diagnosis for the Air Intake System of the SI-Engine. SAE Technical Paper 970209. 1997. https://doi.org/10.4271/970209.

13. Komorska I, Wołczyński Z. Fault diagnostics of air intake system of the internal combustion engine. In book: Advances in Technical Diagnostics. Springer. 2018: 91-100.

14. Komorska I, Wołczyński Z, Borczuch A. Modelbased analysis of sensor faults in SI engine. Combustion Engines. 2017; 169(2): 146-151.

15. Więcławski K, Mączak J, Szczurowski K. Fuel injector diagnostics based on observations of magnetic flux changes. Diagnostyka. 2018;19(3):8993. https://doi.org/10.29354/diag/94040.

16. Puchalski A, Komorska I. Data-driven monitoring of the gearbox using multifractal analysis and machine learning methods. MATEC Web of Conferences. 2019; 252 .

https://doi.org/10.1051/matecconf/201925206006

17. Jack LB, Nandi AK. Fault detection using support vector machines and artificial neural networks, augmented by genetical algorithms. Mechanical Systems and Signal Processing 2002;16(2-3): 373390. https://doi.org/10.1006/mssp.2001.1454.

18. Czech P, Łazarz B, Wilk A. Application of neural networks for detection of gearbox faults. WCEAM CM 2007. Harrogate, United Kingdom.

19. Czech P, Wojnar G, Burdzik R, Konieczny $Ł$, Warczek J. Application of the discrete wavelet transform and probabilistic neural networks in IC engine fault diagnostics. Journal of Vibroengineering. 2014; 16(4): 1619-1639.

20. Strączkiewicz M, Barszcz, T. Application of artificial neural network for damage detection in planetary gearbox of wind turbine. Shock and Vibration. 2016: 1-12. https://doi.org/10.1155/2016/4086324.

21. Chen P. Study on neural network automobile fault diagnosis expert system. Journal of Applied Sciences. 2014; 14(4);348-354.

22. Ogaji SOT, Singh R. Advanced engine diagnostics using artificial neural networks. Applied Soft Computing. 2003; 3(3): 259-271. https://doi.org/10.1016/S1568-4946(03)00038-3.

23. Haykin S. Neural Networks: A comprehensive foundation. Macmillan. New York, 1994.

24. Rojas R. Neural Networks: A systematic introduction. Macmillan College Publishing Company. New York 1994.

Received 2019-03-15

Accepted 2019-07-02

Available online 2019-07-04

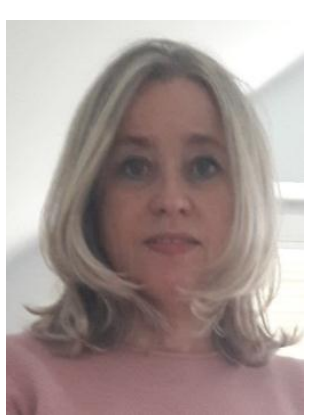

Iwona KOMORSKA, DSc., DEng. - Professor in the Faculty of Mechanical Engineering at the University of Technology and Humanities in Radom. Her current research interests include vibration, data mining, modelling \& simulation, automotive mechatronics.

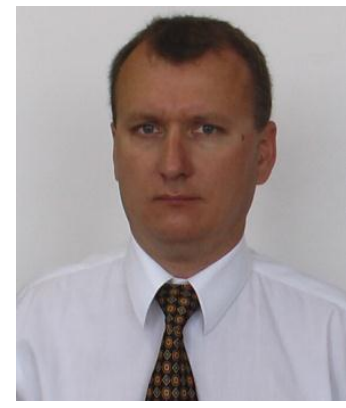

\section{Zbigniew}

WOLCZYŃSKI, DEng. -

Doctor in the Faculty of Mechanical Engineering at the University of Technology and Humanities in Radom. His current research interests include electronics and automotive mechatronics.

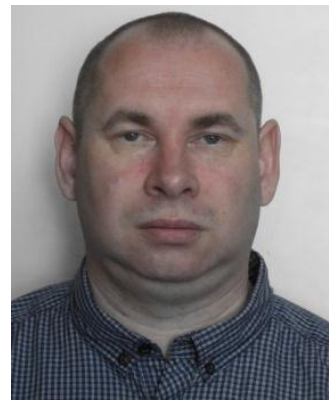

Artur

BORCZUCH,

MEng. - Technical support engineer in the Faculty of Mechanical Engineering at the University of Technology and Humanities in Radom. His current research interests include automotive engineering. 